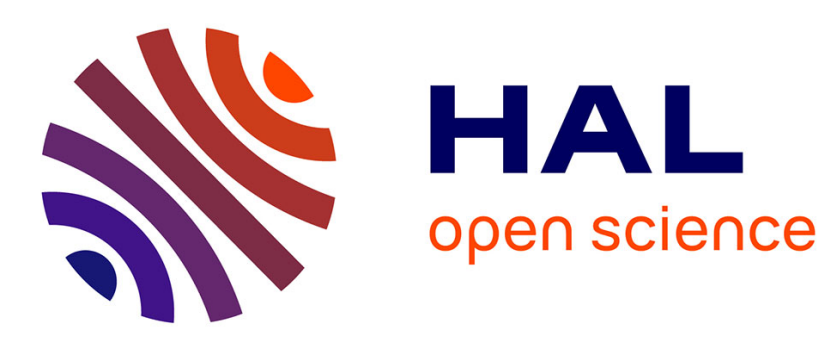

\title{
Effect of Experimental Conditions on 7075 Aluminium Response During Thixoextrusion
}

\author{
Adriana Neag, Véronique Favier, Mariana Pop, Eric Becker, Régis Bigot
}

\section{To cite this version:}

Adriana Neag, Véronique Favier, Mariana Pop, Eric Becker, Régis Bigot. Effect of Experimental Conditions on 7075 Aluminium Response During Thixoextrusion. Key Engineering Materials, 2012, 504-506, pp.345-350. 10.4028/www.scientific.net/KEM.504-506.345 . hal-01090353

\section{HAL Id: hal-01090353 https://hal.science/hal-01090353}

Submitted on 3 Dec 2014

HAL is a multi-disciplinary open access archive for the deposit and dissemination of scientific research documents, whether they are published or not. The documents may come from teaching and research institutions in France or abroad, or from public or private research centers.
L'archive ouverte pluridisciplinaire HAL, est destinée au dépôt et à la diffusion de documents scientifiques de niveau recherche, publiés ou non, émanant des établissements d'enseignement et de recherche français ou étrangers, des laboratoires publics ou privés. 


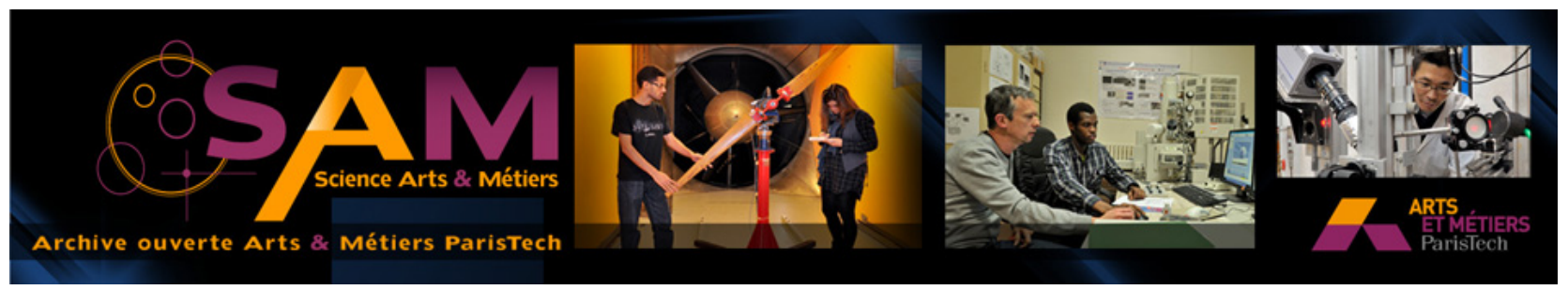

Science Arts \& Métiers (SAM)

is an open access repository that collects the work of Arts et Métiers ParisTech researchers and makes it freely available over the web where possible.

This is an author-deposited version published in: http://sam.ensam.eu

Handle ID: .http://hdl.handle.net/10985/9048

\section{To cite this version :}

Adriana NEAG, Véronique FAVIER, Mariana POP, Eric BECKER, Régis BIGOT - Effect of Experimental Conditions on 7075 Aluminium Response During Thixoextrusion - Key Engineering Materials - Vol. 504-506, p.345-350 - 2012 


\title{
Effect of Experimental Conditions on 7075 Aluminium Response During Thixoextrusion
}

\author{
Adriana NEAG ${ }^{1, a}$, Veronique FAVIER ${ }^{2, b}$, Mariana $\mathrm{POP}^{1, \mathrm{c}}$, Eric BECKER ${ }^{3 \mathrm{~d}}$, \\ Regis BIGOT ${ }^{3 e}$ \\ ${ }^{1}$ Technical University 103-105 Bwd.Muncii, 400641 Cluj-Napoca, Romania \\ ${ }^{2}$ Arts et Métiers ParisTech, PIMM UMR CNRS 8006, 151 Bd.de l'Hopital, 75013 Paris, France \\ ${ }^{3}$ LCFC,EA 4495, Arts et Métiers ParisTech, 4 rue A.Fresnel, 57078 Metz Cedex 3 , \\ France \\ aadriana.neag@ipm.utcluj.ro, ${ }^{b}$ veronique.favier@ensam.eu, 'cmariana.pop@ipm.utcluj.ro, \\ deric.becker@ensam.eu, regis.bigot@ensam.eu
}

Keywords: Semi-solid, 7075 aluminium alloy, thixoextrusion, microstructure

\begin{abstract}
The deformation behavior of semi-solid aluminum alloy is strongly dependent on the microstructure. This paper illustrates several experimental research works concerning thixoextrusion of 7075 aluminum alloy which was carried out at "Arts et Métiers ParisTech" of Metz. Inductive re-heating of the aluminum billet is the method used in order to obtain the target liquid fraction for thixoextrusion. To minimize the heat losses, a sample obtained from a direct extruded bar is inserted in a die for reheating in semisolid state and thixoextrusion. During the experimental re-heating process, the temperature was directly controlled by using thermocouples for temperature measurements in the sample and also in the die. The influence of different working ram speeds and reheating temperature on the microstructure evolution was studied by optical microscopy. The experimental results on extrusion load and microstructure evolution of the component are reported.
\end{abstract}

\section{Introduction}

Thixoextrusion is a semi-solid processing refering to the shaping of metals by extrusion at a temperature between solidus and liquidus. It is a potential technology which can be applied to most engineering alloy families, including aluminum, magnesium, copper and ferrous alloys [1]. In comparison to the conventional hot-extrusion processes, the thixoextrusion processes of aluminium alloys may commonly have some important advantages such as reduction of the extrusion force and friction force between material and tools, higher fluidity of material, longer tool life, high productivity etc. [2]. It requires a non-dendritic microstructure made of solid spheroids surrounded by a liquid matrix in order to obtain thixotropic flow behaviour. Several methods can be used to produce this target microstructure, amongst them there is the RAP (Recrystallisation and partial melting) method [3]. The RAP route involves working the material before reheating at temperatures below the recrystallisation temperature [4]. Rheological behavior of the materials in semi-solid state, the impact of raw material characteristics and the forming process parameters have to be attentively investigated.

The aim of this paper is to provide such information in the case of quasi-isothermal backward extrusion test of 7075 aluminium alloy in the semi-solid state. The billet was heated inside the extrusion die to avoid the convective and radiation heat losses obtained when the billet is directly heated by induction. We show that reheating by induction the steel die and the aluminium billet placed into the die at the same time provides rapidly very homogeneous microstructure suitable for thixoforming. The impact of the ram speed and process temperature on the load-displacement curves was also investigated. 


\section{Experimental materials and procedures}

This part presents the material used to realize the semi-solid experiments, the experimental conditions of thixo-extrusion tests and the extrusion device design.

\section{Material}

The material used for thixoextrusion was a commercial aluminium alloy type 7075 , having the chemical composition as showed in Table 1.

Table 1 Chemical composition of 7075 aluminium alloy.

\begin{tabular}{|l|c|c|c|c|c|c|c|c|}
\hline Element & $\mathrm{Zn}$ & $\mathrm{Mg}$ & $\mathrm{Cu}$ & $\mathrm{Cr}$ & $\mathrm{Fe}$ & $\mathrm{Si}$ & $\mathrm{Ti}$ & $\mathrm{Al}$ \\
\hline \%wt & $5.1-6.1$ & $2.1-2.9$ & $1.2-2$ & $0.18-0.28$ & $\max 0.5$ & $\max 0.4$ & $\max 0.2$ & bulk \\
\hline
\end{tabular}

The as-received alloy was extruded with an extrusion ratio of 16:1. After extrusion the material was T6 heat treated. The slugs are obtained by cutting extruded bars. The volume of the slug is chosen to fully fill the extrusion tool. For these tests before partial remelting, the bar was machined into cylindrical slug with the dimensions of $40 \mathrm{~mm}$ in diameter and $28 \mathrm{~mm}$ high.

The 7075 aluminium alloy shows by DSC analysis a less sensitive solid fraction to temperature variation at high solid fraction [5]. This is the reason why we chose the working temperature window equal to $\left[580-617^{\circ} \mathrm{C}\right]$ in order to get a not too high solid fraction (ranging from 0.9 up to 0.7) required to get thixotropic behaviour but also a not too low solid fraction to get a reliable process.

Following metallographic preparation and etching in Keller solution, the specimens were examined by light microscopy and quantitative image analysis using the ImageJ software. The mean grain size was measured using a mean linear intercept method. The shape factor was calculated using the equation $\mathrm{F}=4^{*} \pi^{*} \mathrm{~A} / \mathrm{P}^{2}$ where $\mathrm{A}$ and $\mathrm{P}$ are the area and the perimeter of the globule, respectively.

\section{Experimental procedure}

Semisolid manufacturing requires heating the slug to the semisolid state with coexisting liquid and solid phases. To heat to the semisolid temperature, an induction heating method was used because it is non-contact, compact and fast method and the input power can be easily controlled. The reheating was performed using an induction system used in the LCFC laboratory from the "Arts et Métiers ParisTech" Metz (Fig. 1). The inductor was designed to perform the reheating of the die containing the slug and to allow the backward extrusion test through the induction coil in order to avoid the transfer of the slug (Fig.1a). So, the thixoextrusion die containing the initial extruded billet was positioned in the center of the inductor coil and was placed on an Inconel special ceramic support in order to be thermally insulated. The frequency of the electrical generator ranged between 10-30 kHz. The electrical power was $25 \mathrm{~kW}$. This heating system is controlled by an electronic device which programs the reheating cycles, and these cycles are repeatable and allow a quasiuniform temperature distribution in the slug [6]. During reheating, two „K” type thermocouples were inserted to monitor the temperature evolution: the first one into the centre of the slug and the

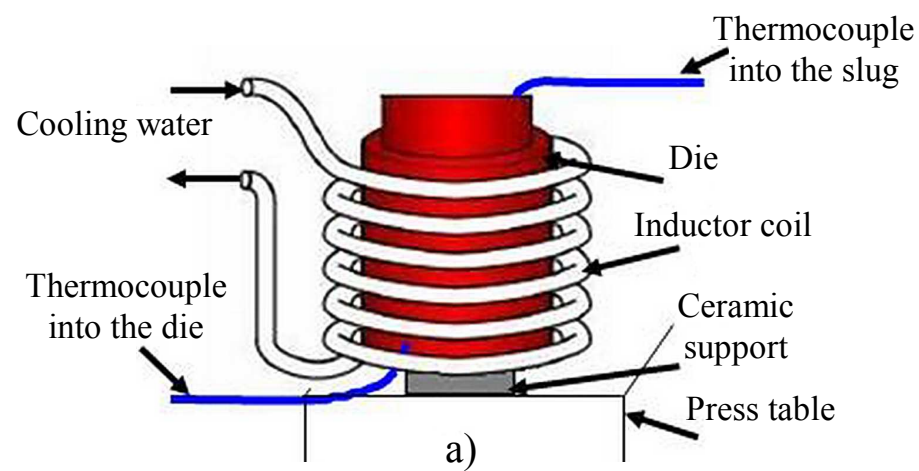

b)

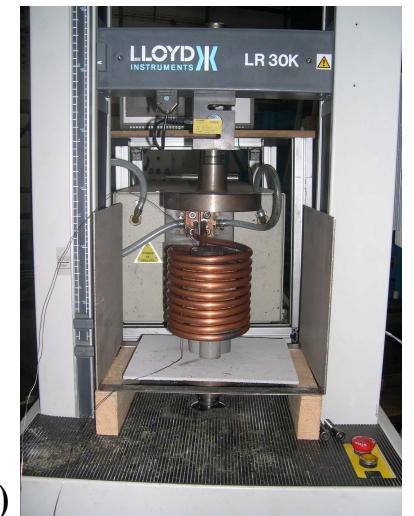

Fig. 1 a) Induction heating process scheme; b) Extrusion device on the Lloyd press 
second one was into the die at less than $5 \mathrm{~mm}$ from the slug surface. The heating route consisted in 4 successive power stages (obtained by trial and error procedure) to ensure a homogeneous temperature in the slug. Typically, the complete heating cycle lasted $13 \mathrm{~min}$ so that the average heating speed was about $45^{\circ} \mathrm{C} / \mathrm{min}$. Note that in this case, the heat sources are generated by Foucault currents induced by the electromagnetic field within the metal. The induction frequency is about 10$30 \mathrm{kHz}$, so that the penetration depth of the Foucault currents is about $1 \mathrm{~mm}$ from the die surface. After semi-solid holding completion, the thixoextrusion tests were carried out on the hydraulic 200 $\mathrm{kN}$ press (Fig.1b). In addition, a Nefacier 1500 C) board was placed between the Inconel support and the table press to reduce heat losses. A tool protector coating (Acheson Pulvegraph D31A) is sprayed after each extrusion test to protect tool surface against wear and chemical attack of aluminium on steel. Upon reaching the desired temperature and holding time, the electric power of the induction system was shut down and the thermocouple which was in the center of the slug (Fig.1a) was extracted. The backward extrusion test was then immediately carried out through the induction coil in order to avoid the transfer of the slug. Hence, quasi-isothermal conditions are obtained. The slugs were thixoextruded at a constant ram speed $(2 ; 6$ and $8.5 \mathrm{~mm} / \mathrm{s})$ and the displacement of superior die is limited on the inferior die. After heating and forming, the set was water quenched.

\section{Results and discussions}

\section{Effect of induction reheating on microstructure evolution of 7075 aluminium alloy}

Microstructure characteristics were studied using an optical microscope (Olympus Provis) connected to an image analysis system. Figure 2a shows the microstructure of the as-received alloy, which consisted on unrecrystallised primary $\alpha(\mathrm{Al})$ elongated grains, aligned in the extrusion direction, with the grain boundaries well delineated. This one was turned into globular microstructure (Fig.2b), by RAP (Recrystallisation and partial melting) route [7]. In the figure 2b),
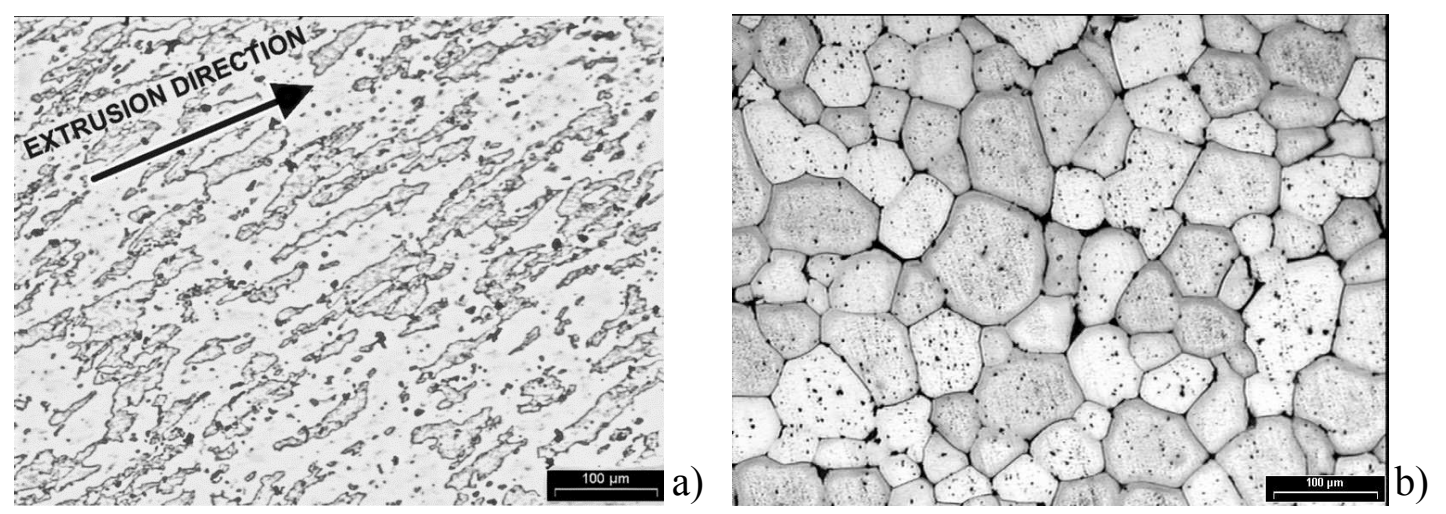

Fig. 2 Microstructure of 7075 aluminium alloy: a) (T6) extruded; b) sample reheated to $580^{\circ} \mathrm{C}$ (etched Keller 10s)
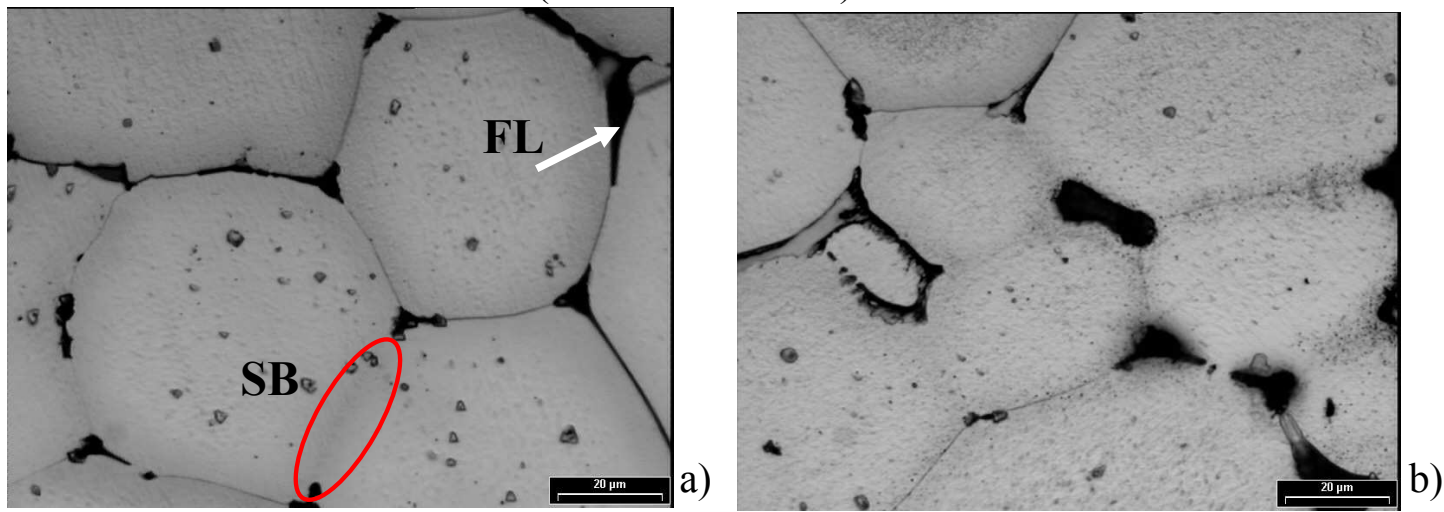

Fig. 3 Microstructure of 7075 aluminium alloy reheated to $580^{\circ} \mathrm{C}$ : a) transversal section; b) longitudinal section. 
the light primary solid phase and the dark eutectic phase, corresponding to the solid phase and to the liquid phase which are supposed to be present in the semi-solid state. The average grains size of 7075 aluminum alloy quenched after 13 min induction reheating does not exceed $70 \mu \mathrm{m}$.

The microstructure contains almost perfectly globular recrystallised grains and the intragranular liquid droplets are homogeneously distributed in the grains. The particles are surrounded by solid bonds "SB" and the free liquid "FL" (Fig.3). The solid fraction is 0.87 in the cross section and 0.81 in the longitudinal section of the slug (studied by ImageJ analyses). The solid particles are uniformly distributed on the cross section surface and the shape factor is around 0.95 after 13 minutes induction reheating.

\section{Effect of thixoextrusion tests on microstructure evolution of 7075 aluminium alloy}

Image analyses have been done on three different regions of parts (fig.4). For this purpose, the surfaces of the walls were prepared along the longitudinal axes of the part. A globular structure of the primary $\mathrm{Al}$ phase, similar to that found in figure $2 \mathrm{~b}$ obtained after reheating is observed in the whole section of the extruded part. The part on the figure 4 was formed at $609^{\circ} \mathrm{C}(0.76 \mathrm{DSC}$ solid fraction) and $6 \mathrm{~mm} / \mathrm{s}$ ram speed. The quantitative results obtained by ImageJ analyses, show that the solid fraction is about 0.74 at the upper part of the cup (zone 1) and slowly increases up to 0.80 at the bottom of the cup (zone 3). A slight segregation of the liquid during the thixoforming process

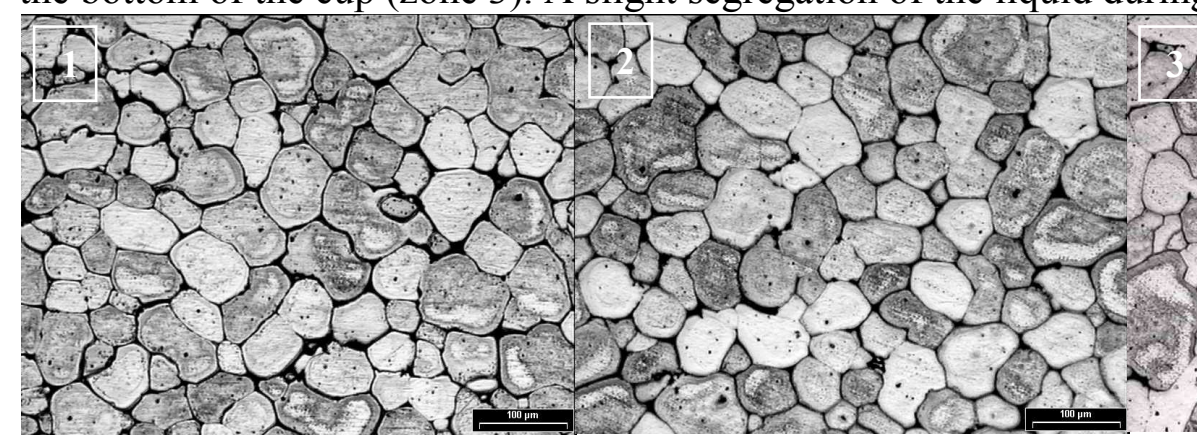

Fig. 4 Vertical section view of the thixoextruded part and the interest zones of microstructure observation

was observed. Forming at this temperature, reveal sliding between solid phase and liquid phase without any plastic deformation. We consider that in these conditions, the solid grains are very weakly connected and most of grain boundaries are wetted by a thin liquid film.

\section{The impact of the process conditions on the extrusion results}

Figure 5 shows the loaddisplacement responses for three temperatures: $602^{\circ} \mathrm{C}, \quad 609^{\circ} \mathrm{C}$ and $617^{\circ} \mathrm{C}$. These temperatures correspond to solid fraction of $0.82,0.77$ and 0.69 , respectively. The load-displacement curve can be divided into four stages and the range is from 0 to $30 \mathrm{kN}$ about. The first stage associated with zero force corresponds to the motion of the upper ram until it touches the upper part of the die. Then, the slug is compressed and fills the lower part of the component (stage II). The stages

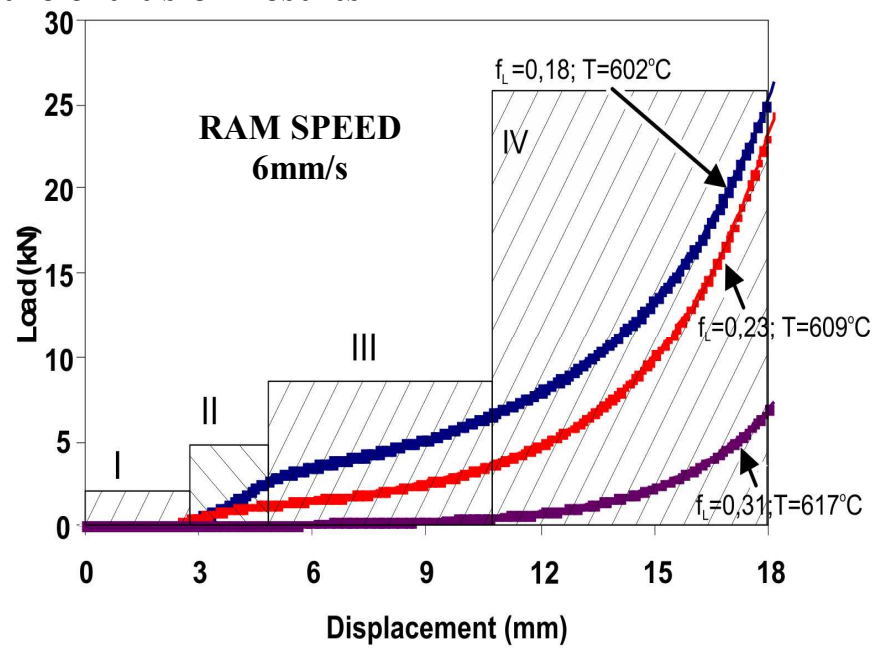

Fig.5 Load-displacement responses during thixoextrusion at low ram speed $(6 \mathrm{~mm} / \mathrm{s})$ and different temperatures. 
III and IV are related to the backward extrusion and the filling of the cup. During this filling, the contact area between the slug and the die increases. As a result, the load rises due to the increasing friction. The load clearly decreased with decreasing solid fraction. This result is expected and consistent with literature data for any semi-solids. At $\mathrm{f}_{\mathrm{s}}=0.69$, the material does not display sufficient resistance to be measured by the load cell (sensor sensitivity lower then the load) until the stage IV. In addition, it was difficult to remove the cup from the upper part of the die due to a strong adherence. Also, the cup was found with a very bad surface quality while the cup displayed a much better surface quality for 0.77 and 0.82 solid fraction. As $\mathrm{f}_{\mathrm{s}}=0.77$ appears as a good compromise to get lower load and a good parts surface quality.

Figure 6 presents the loaddisplacement evolution during the thixoextrusion process at $610^{\circ} \mathrm{C}$ and for three values of the working ram speed. We observed that the load increases with the increase of the ram speed. This result suggests that the semi-solid behaves as a classical viscoplastic material. It is consistent with the micrographs (Fig. 4) which revealed any significant changes in microstructure during the

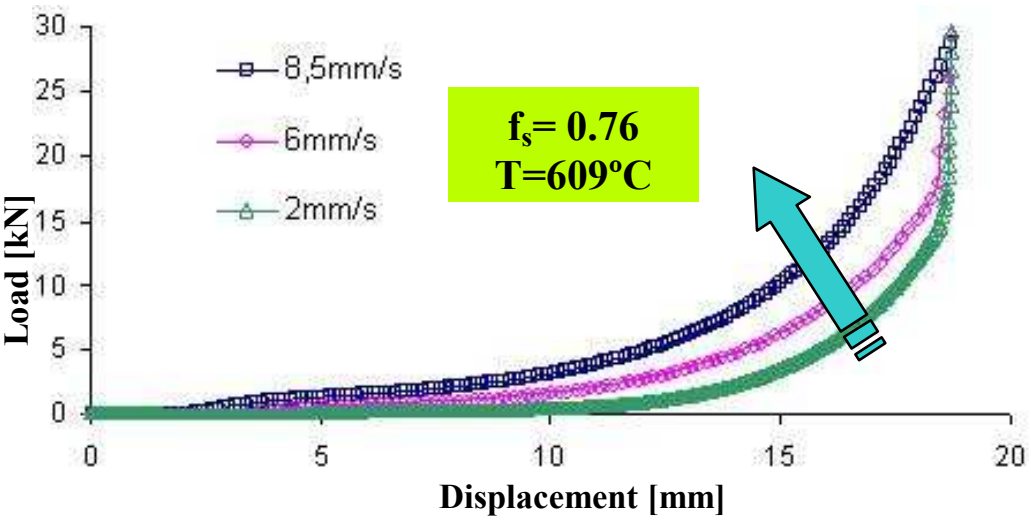

Fig.6 Load-displacement evolution during thixoextrusion at the same temperature and different ram speed forming process.

\section{Conclusion}

The experiment study described above clearly showed that:

- Reheating the previously extruded 7075 aluminium billet inside the steel die by an induction furnace provides a homogenous microstructure after about 13 minutes at $580^{\circ} \mathrm{C}$ temperatures. This microstructure is made of globular solid grains surrounded by thin liquid film, which is suitable for thixoforming.

- The slug temperature and the working ram speed strongly impact the load required for filling. As expected, decreasing temperature, and so the solid fraction, increases the forming load. Increasing the ram speed increases the forming load.

- During the quasi isothermal thixo backward extrusion tests, the flow remains quasi homogeneous. Deformation takes place by rearrangement of the globules with respect to each other without any plastic deformation. Thus, despite the high solid fraction $(>0.75)$, the solid particles are weakly connected. The semi-solid is found to behave as a classical viscoplastic material without any significant changes in microstructure during the forming process.

\section{Acknowledgment}

This paper was supported by the project "Develop and support multidisciplinary postdoctoral programs in primordial technical areas of national strategy of the research-development-innovation" 4D-POSTDOC, contract nr. POSDRU/89/1.5/S/52603, project co-funded from European Social Fund through Sectorial Operational Program Human Resources 2007-2013. The authors gratefully acknowledge the support of "LCFC" laboratory from "Arts et Métiers ParisTech" Metz. 


\section{References}

[1] P. Kapranos, D.H. Kirkwood, C.M. Sellars, Semi-solid processing of tool steel, J.Physique IV, (3) (1993) 835-840.

[2] H.V. Atkinson, Modelling the semisolid processing of metallic alloys, Progress in Materials Sci. 50 (2005) 341-412.

[3] M. Suery, Mise en forme des alliages métalliques à l'état semi-solide, Traité MIM Mecanique et Ingénierie des Matériaux, Ed. Lavoisier, 2002.

[4] H.V. Atkinson, K. Burke, G. Vaneetveld, Recristalisation in the semi-solid state in 7075 aluminum alloy, Mater.Sci.Eng. A, 490 (2008) 266-276.

[5] G. Vaneetveld, A. Rassili, H.V. Atkinson, Influence of parameters during induction heating cycle of 7075 aluminium alloys with RAP process, Solid State Phenomena Vols. 141-143 (2008) 719-724.

[6] A. Neag, V. Favier, R. Bigot, D. Frunză, Study on Thixo-extrusion of Semi-solid aluminium, $10^{\text {th }}$ Int.Conf. Semi-Solid Processing of Alloys and Composites, Aachen-Liege, (2008) 659-664.

[7] K.P. Young, C.P. Kyonka, J.A. Courtois, Fine grained metal composition, US Patent no. 4,415,374, 30 March, (1982). 
